\title{
Pengaruh Fase Oral Terhadap Perkembangan Anak
}

\author{
Yuanita Wardianti ${ }^{1)}$ dan Dian Mayasari ${ }^{2)}$ \\ ${ }^{1)}$ Prodi Bimbingan dan Konseling STKIP Singkawang \\ e-mail: yuanita.w16@gmail.com \\ ${ }^{2)}$ Prodi Bimbingan dan Konseling STKIP Singkawang \\ e-mail: diansingkawang@gmail.com
}

\begin{abstract}
Abstrak. Rumusan dalam makalah ini adalah: (1) Apakah pengertian perkembangan anak?, Apakah fase oral mempengaruhi perkembangan anak?. Makalah ini bertujuan untuk mengetahui pengertian perkembangan anak serta mengetahui pengaruh fase oral terhadap perkembangan anak. Metode yang digunakan adalah kajian literatur. Hasil makalah menunjukkan: (1) perkembangan adalah proses kematangan seorang individu yang mengacu pada penyempurnaan fungsi sosial dan psikologis dalam diri seseorang dan berlangsung sepanjang hidup; (2) Ketidakpuasan pada masa oral dapat menimbulkan gejala regresi (kemunduran) dan gejala perasaan iri hati(cemburu) serta akan berdampak kurang baik bagi perkembangan kepribadian anak. Kepuasan yang berlebihan pada fase oral juga membentuk oral incorporation personality pada masa dewasa.
\end{abstract}

Kata kunci: fase oral, perkembangan anak

\section{Pendahuluan}

Perkembangan berjalan menurut norma-norma tertentu. Walaupun demikian seorang anak dalam banyak hal tergantung kepada orang dewasa, misalnya mengkunsumsi makanan, perawatan, bimbingan, perasaan aman, pencegahan penyakit dan sebaginya. Oleh karena itu semua orang yang mendapat tugas mengawasi anak harus mengerti persoalan anak yang sedang tumbuh dan berkembang. Untuk mencapai dewasa, sebagain individu seorang anak harus melampaui beberapa fase perkembangan. Setiap fase perkembangan mempunyai tugas-tugas perkembangan yang harus dilakukan [4].

Kegagalan dalam menyelesaikan tugas perkembangan ini, dapat mempengaruhi perkembangan pada fase berikutnya, sehingga dapat menimbulkan gangguan, misalnya seorang anak yang tidak dapat menyelesaikan tugas perkembangan pada fase oral dapat mengakibatkan anak tersebut mengalami kesulitan dalam membina hubungan saling percaya dengan orang lain, rendah diri, tidak merasa bahagia dan pada akhirnya dapat menurunkan kualitas anak serta dapat berdampak buruk pada masa dewasa [4], [6], [8].

\section{Pembahasan}

Pengertian Perkembangan

"Perkembangan secara luas menunjukan pada keseluruhan proses perubahan dari potensi yang dimiliki individu dan tampil dalam kualitas kemampuan, sifat dan ciri-ciri yang baru [3]. Dalam istilah perkembangan juga tercakup konsep usia, yang di awali dari saat pembuahan dan berakhir kematian". Pengertian perkembangan menunjuk pada " Proses yang kekal dan tetap yang menuju ke arah suatu organisasi pada tingkat integrasi yang lebih tinggi, berdasarkan pertumbuhan, pematangan, dan belajar [7]."

Perkembangan sebagai: (1) perubahan yang berkesinambungan dan progresif dalam organisme, dari lahir sampai mati, (2) pertumbuhan, (3) perubahan dalam bentuk dan dalam integrasi dalam bagian-bagian jasmaniah ke dalam fungsional, (4) kedewasaan atau kemunculan pola-pola asasi dari tingkah laku yang tidak di pelajari [2]. Dapat disimpulkan bahwa perkembangan anak adalah proses kematangan seorang individuyang mengacu pada penyempurnaan fungsi sosial dan psikologis dalam diri anak dan berlangsung sepanjang hidup

Faktor-faktor yang mempengaruhi perkembangan diantaranya: (1) Faktor hereditas (warisan sejak lahir/ bawaan; (2) Faktor Lingkungan; (3)Kematangan fungsifungsi organis dan psikis; (4) Aktifitas anak sebagai subyek bebas yang berkemauan, kemampuan seleksi, bisa menolak atau menyetujui, punya emosi, serta usaha membangun diri sendiri.

Tahapan-tahapan perkembangan menurut Sigmund Freud: (1) Masa oral (0-2 tahun),bayi merasakan rasa senang,rangsangan benda, dll; (2) Masa anal (2-4 tahun), bayi merasakan kesenangan ketika buang air besar; (3) Masa falik (4-6 tahun), anak merasa senang jika ada rangsangan atau sentuhan pada kelaminnya; (4) Masa latensi (6-12 tahun), dorongan seksual anak masih belum Nampak; (5) Masa genital (12 tahun sampai dewasa),merupakan masakanak menjadi dewasa". Puncak perkembangan jiwa itu ditandai dengan adanya proses perubahan dari kondisi "entropy" ke kondisi "negen-tropy" [10]. 
Fase Oral Mempengaruhi Perkembangan Anak

Freud membagi berkembangan kepribadian menjadi tiga tahapan yaitu tahan infantil (0-5 tahun), tahan latin (512tahun), dan tahap genital (<12tahun). Tahap infantil merupakan tahan yang paling menentukan dalam membenuk kepribadian, terbagi menjadi tiga fase yaitu fase oral, fase anal, fase falis. Pada fase oral mulut merupaka daerah pokok aktifitas dinamik tau daerah kepuasan seksual yang di pilih oleh insthink seksual.

Mulut sangat penting untuk makan, dan bayi merasakan kesenangan dari rangsanga oral melaui kegiatan memuaskan seperti mencicipi dan mengisap. Karena bayi sepenuhnya bergantung pada pengasuh (yang bertanggung jawab untuk member makan bayi, bayi juga mengembangkanrasa kepercayaan dan kenyamanan melalui setimulusi oral. Konflik utama pada tahap ini adalah prioses penyapihan, anak harus menjadi kurang bergantung pada para pengasuh.

Ketidakpuasan pada masa oral (seperti disapih dan kelahiran adiknya) dapat menimbulkan gejala regresi (kemunduran) yaitu berbuat seperti bayi atau anak yang sangat bergantung kepada orang tuanya atau banyak tuntutan yang harus dipenuhi dan juga gejala perasaan iri hati(cemburu). Reaksi dari kedua gejala tersebut dapat dinyatakan dalam beberapa tingkah, seperti: menghisap jempol, mengompol, membandel dan membisu seribu bahasa.

Ketidakpuasan ini juga akan berdampak kurang baik bagi perkembangan kepribadian anak, seperti: merasa kurang aman, selalu meminta perhatian orang lain atau egosentris. Sama halnya dengan anak yang tidak mendapat kepuasan, secara berlebihan pun ternyata berdampak kurang baik terhadap perkembangan kepribadiannya. Dia akan menampilkan pribadi yang kurang mandiri (kurang bertanggung jawab), bersikap rakus dan haus perhatian atau cinta orang lain. Menurut Freud, fiksasi pada tahap ini dapat membentuk sikap obsesif yaitu makan dan merokok pada kehidupan berikutnya (masa remaja dan dewasa). Pada tahap ini juga dorongan agresi sudah mulai berkembang [10].

Selain itu kepuasan yang berlebihan pada fase oral, akan membentuk oral incorporation personality pada masa dewasa, yakni orang menjadi senang/fiksasi mengumpulkan pengetahuan atau mengumpulkan harta benda, atau gampang ditipu (mudah menelaah perkataan orang lain). Sebaliknya, ketidakpuasan pada fase oral ini, sesudah dewasa orang menjadi tidak pernah puas, tamak (memakan apa saja) dalam mengumpulkan harta. Oral agession personality oleh kesenangan berdebat dan sikap sarkatik, bersumber dari sikap protes bayi (menggigit) terhadap perlakuan ibu dalam menyusui. Mulut sebagai daerah erogen, terbawa sampai dewasa dalam bentuk yang lebih bervariasi, mulai dari mengunyah permen karet, menggigit pensil, senang makan, menghisap rokok, menggunjing orang lain, sampai berkata-kata kotor/sarkatik [1].

\section{Simpulan dan Saran}

Simpulan

Perkembangan anak adalah proses kematangan seorang individu yang mengacu pada penyempurnaan fungsi sosial dan psikologis dalam diri seseorang dan berlangsung sepanjang hidup.

Ketidakpuasan pada masa oral dapat menimbulkan gejala regresi (kemunduran) dan gejala perasaan iri hati(cemburu) serta akan berdampak kurang baik bagi perkembangan kepribadian anak. Kepuasan yang berlebihan pada fase oral juga membentuk oral incorporation personality pada masa dewasa.

\section{Saran}

Sebaiknya, orang tua terutama ibu lebih memperhatikan pemenuhan kebutuhan pemuasan fase oral untuk perkembangan bayi, karena fase oral ini hanya berlangsung hingga 18 bulan.

Selanjutnya, peneliti yang ingin mengakji atau meneliti tentang pengaruh fase oral terhadap perkembangan anak, dapat menggunakan hasil makalah sebagai kajian teori dalam penelitiannya.

\section{Referensi}

[1] Alwisol. 2011. Psikologi Perkembangan. Malang: UMM PRESS.

[2] Chaplin, J.P. 2002. Dictionary of psychology, terjemahan. Kartini Kartono. Jakarta: Raja Grafindo Persada.

[3] Hawari, Reni Akbar. 2011.Psikologi Perkembangan Anak: Mengenal sifat, bakat, dan Kemampuan Anak. Jakarta: Grasindo.

[4] Hurlock, EB. 1980. Development Psychology: A Life Span Approach, Edisi 5, Jakarta: Erlangga.

[5] Ikalor , Allvanialista, 2013. "Pertumbuhandan Perkembangan”. Jurnal Pertumbuhan dan Perkembangan vol. 7 Nomor 1, Mei 2013.

[6] Kozier and Erb. 2000. Fundamental of Nursing; Consept,Prosess \& Practice, 4 th, Philadelphia: CV. Mosby Company.

[7] Monks, F J., dkk. 2001. Psikologi Perkembangan: Pengantar dalam Berbagai Bagiannya. Yogyakarta: UGM.

[8] Nurhidayah, Siti, 2011. Kelekatan (Attachment) dan Pembentukan Karakter Vol. 7, No. 2.

[9] Pootter and Perry. 1997. Fundamental of Nursing: Consept, Process and Practice, Forth edition, St. Louis: CVMosby Company.

[10] Sarwono, Sarlito W. 1991. Pengantar Psikologi Umum. Jakarta: Rajawali

[11] Yusuf, Syamsu dan Achmad Juntika Nurihsan. 2011.Teori Kepribadian.Bandung: Remaja Rosdakarya.

[12] Wijayanti, Rahayu \& Purwandari, Haryatiningsih, "Dampak Penggunaan Modul Terhadap Peningkatan Pengetahuan dan Ketrampilan Keluarga Dalam Menstimulasi Tumbuh Kembang Bayi "Jurnal Keperawatan Soedirman (The Soedirman Journal of Nursing), Volume 1, No.2, November 2006. 